\title{
FAKTOR-FAKTOR YANG BERHUBUNGAN DENGAN KEJADIAN ISPA PADA BALITA
}

\author{
FACTORS THAT ARE RELATED TO THE ISPA EVENTS IN CHILDREN \\ Berta Afriani \\ Akademi Keperawatan Al-Ma'arif Baturaja, Jl Dr Mohammad Hatta No 687-B Sukaraya, \\ Baturaja, Sumatera Selatan, Indonesia 32112, Kab. Ogan Komering Ulu, Sumatera Selatan, \\ Indonesia \\ Email: afrianiberta974@gmail.com
}

\begin{abstract}
ABSTRAK
ISPA pada balita merupakan penyebab utama kematian balita di dunia. Survei mortalitas yang dilakukan oleh Subdit tahun 2013 menempatkan ISPA sebagai penyebab kematian balita terbesar di Indonesia dengan persentase 32,10\% dari seluruh kematian balita. Tuuan penelitian ini untuk diketahuinya faktor-faktor yang berhubungan dengan kejadian ISPA pada balita. Metode penelitian ini menggunakan desain penelitian Cross Sectional. Populasi dalam penelitian ini adalah jumlah seluruh balita yang terdapat di desa suka pindah Kabupaten OKU, besar sampel yang di teliti adalah sebanyak 144 balita. Hasil uji statistik chi-square di peroleh p value 0,000 antara pemakaian obat nyamuk bakar, perilaku merokok, kepadatan hunian dengan kejadian ISPA pada balita, dan p value 0,001 ventilasi asap dapur dengan kejadian ISPA pada balita. Ada hubungan yang bermakna antara pemakaian obat nyamuk bakar, perilaku merokok, ventilasi asap dapur, kepadatan hunian.
\end{abstract}

Kata Kunci: ISPA, Balita

\begin{abstract}
ISPA in infants is the main cause of infant mortality in the world. Mortality survey conducted by Subdit in 2013 places ISPA as the biggest cause of under-five mortality in Indonesia with a percentage of $32.10 \%$ of all under-five deaths. The purpose of this study is to determine the factors associated with ISPA in infants. This research method uses a cross sectional research design. The population in this study is the total number of children under five in the village like to move OKU Regency, the sample size is 144 children under five. Chi-square statistical test results obtained $p$ value 0,000 between the use of mosquito coils, smoking behavior, occupancy density with ISPA events in infants, and p value 0.001 kitchen smoke ventilation with ISPA events in infants. There is a significant relationship between the use of mosquito coils, smoking behavior, kitchen smoke ventilation, occupancy density.
\end{abstract}

Keywords: ISPA, Toddler 


\section{PENDAHULUAN}

Pembangunan kesehatan pada hakekatnya adalah upaya yang dilaksanakan oleh semua komponen Bangsa Indonesia yang bertujuan untuk meningkatkan kesadaran, kemauan, dan kemampuan hidup sehat bagi setiap orang agar terwujud derajat kesehatan masyarakat yang setinggi-tingginya. Infeksi Saluran Pernafasan Akut (ISPA) merupakan salah satu penyebab utama kematian pada balita didunia. Penyakit ini paling banyak terjadi di negaranegara berkembang di dunia. Populasi penduduk yang terus bertambah dan tidak terkendali mengakibatkan kepadatan penduduk di suatu wilayah yang tidak tertata baik dari segi aspek sosial, budaya dan ${ }^{1}$. Kondisi ini akan bertambah buruk dengan status sosial ekonomi keluarga yang rendah atau berada dibawah garis kemiskinan karena tidak dapat memenuhi asupan gizi yang baik dan sehat untuk balita ditambah dengan kondisi fisik rumah yang tidak layak tinggal ${ }^{2}$.

ISPA pada balita merupakan penyebab utama kematian balita di dunia. Penyakit ini menyumbang $16 \%$ dari seluruh kematian anak di bawah 5 tahun, yang menyebabkan kematian pada 920.136 balita, atau lebih dari 2.500 per hari, atau di perkirakan 2 anak Balita meninggal setiap menit pada tahun $2015^{3}$.

Penyakit ISPA di Indonesia berada pada 10 daftar penyakit terbanyak di rumah sakit. Survei mortalitas yang dilakukan oleh Subdit tahun 2013 menempatkan ISPA sebagai penyebab kematian balita terbesar di
Indonesia dengan persentase $32,10 \%$ dari seluruh kematian balita ${ }^{4}$.

Berdasarkan dari data Dinas kesehatan provinsi Sumatera Selatan data hasil laporan ISPA pada tahun 2017 terdapat dua provinsi yang cakupan penemuan pneumonia balita sudah mencapai target yaitu DKI Jakarta 98,54\% dan Kalimantan Utara $81,39 \%$, sedang provinsi yang lain masih di bawah target $80 \%$, capaian terendah di provinsi Papua $0,60 \%$. Angka kematian akibat pneumonia pada balita tahun 2016 sebesar $0,22 \%$ pada tahun 2017 menjadi $0,34 \%$. Pada tahun 2017, Angka kematian akibat Pneumonia pada kelompok bayi lebih tinggi yaitu sebesar 0,56\% dibandingkan pada kelompok anak umur $1-4$ tahun sebesar 0,23\%. Cakupan penemuan pneumonia dan kematiannya menurut provinsi dan kelompok umur pdaa tahun $2017^{4}$.

Berdasarkan data dinas kesehatan Kabupaten Ogan Komering Ulu tahun 2017, angka kejadian ISPA pada balita sebanyak 7,768 $(20,8 \%)$ kasus ISPA pada balita yg terajdi di wilayah kerja dinas kesehatan Kabupaten Ogan Komering Ulu,dan pada tahun 2018 angka kejadian ISPA pada balita meningkat sebanyak 6,914 (18,6\%) kasus ISPA pada balita yang terjadi dinas kesehatan Kabupaten Ogan Komering $\mathrm{Ulu}^{5}$.

Di UPTD Puskesmas Kedaton sendiri tedapat 316 kunjungan ispa pada balita dari $180(79,6 \%)$ kasus yang terjadi diantaranya terjadi pada balita 1-5 tahun di tahun 2017, dan pada tahun 2018 terdapat 471 kunjungan ispa pada balita dari 190 
$(84,0 \%)$ kasus yang terjadi di UPTD puskesmas kedaton ${ }^{6}$.

Berdasarkan data dari Puskesmas Kedaton Peninjauan Raya, Desa Sukapindah di dapatkan kasus ISPA pada balita di tahun 2017 terdapat 58 kasus (25,6\%) dari 226 jiwa balita,dan pada tahun 2018 terdapat $90(39,8 \%)$ kasus dari 226 jiwa balita.

Berdasarkan survei pendahuluan di Desa Sukapindah tingginya kejadian ISPA pada balita di UPTD Puskesmas Kedaton Peninjauan Raya dari tahun ke tahun, maka penulis tertarik untuk meneliti hubungan pemakaian obat nyamuk bakar,perilaku merokok, ventilasi asap dapur dan kepadatan hunian dengan kejadian ISPA pada balita di Desa Sukapindah wilayah kerja UPTD Puskesmas Kedaton Peninjauan Raya Kabupaten OKU tahun 2019. 
CENDEKIA MEDIKA

April 2020 p-ISSN: 2503-1392

e-ISSN: 2620-5424

\section{METODE}

Desain penelitian yang digunakan adalah desain penelitian Cross Sectional, dimana variabel independen dan variabel dependen di observasi pada saat yang sama.

Dalam penelitian ini yang dimaksud dengan variabel independen adalah pemakaian obat nyamuk bakar,prilaku merokok,ventilasi asap dapur,kepadatan hunian. Variabel dependen dalam penelitian ini adalah kejadian ISPA pada balita.

\section{Volume 5 Nomor 1 ,}

Populasi dalam penelitian ini adalah jumlah seluruh balita yang terdapat di desa suka pindah Kabupaten OKU yang berjumlah 226 besar sampel yang di teliti adalah sebanyak 144 balita. Data dikumpulkan melalui wawancara dengan menggunakan daftar pertanyaan (kuesioner) dan observasi (checklist). Analisa yang digunakan yaitu analisa univariat dan bivariat. 
CENDEKIA MEDIKA

Volume 5 Nomor 1,

April 2020 p-ISSN: 2503-1392

e-ISSN: 2620-5424

HASIL

Analisa Univariat ISPA pada balita

Tabel 1

Distribusi Frekuensi ISPA Pada Anak Balita

\begin{tabular}{llll}
$\mathbf{N o}$ & ISPA pada balita & Frekuensi & $\mathbf{\%}$ \\
\hline $\mathbf{1}$ & ISPA & 90 & $62,5 \%$ \\
\hline $\mathbf{2}$ & Tidak ISPA & 54 & $37,5 \%$ \\
\hline & Jumlah & 144 & 100 \\
\hline
\end{tabular}

Berdasarkan Tabel 1 dari 144 proporsi $(62,5 \%)$ dan responden anak sampel di dapatkan distribusi frekuensi bahwa anak balita yang menderita ISPA sebanyak 90

balita yang tidak menderita ISPA sebesar 54 proporsi (37.5\%).

Pemakaian Obat Nyamuk Bakar

Tabel 2

Distribusi Frekuensi ISPA Pada Anak Balita

\begin{tabular}{llll} 
No & Pemakaian obat nyamuk bakar & Frekuensi & \% \\
\hline $\mathbf{1}$ & Pakai & 88 & $61,1 \%$ \\
\hline $\mathbf{2}$ & Tidak pakai & 56 & $38,9 \%$ \\
\hline & Jumlah & 144 & 100 \\
\hline
\end{tabular}

Berdasarkan Tabel 2 di atas dari 144 sampel di dapatkan distribusi frekuensi bahwa anak balita yang menderita ISPA sebanyak 88

Perilaku merokok

Tabel 3

Distribusi Frekuensi ISPA Pada Anak Balita Di Desa Sukapindah Wilayah Kerja UPTD Puskesmas Kedaton Peninjauan Raya Kabupaten OKU Tahun 2019

\begin{tabular}{llll} 
No & Perilaku merokok & Frekuensi & \% \\
\hline 1 & Merokok & 108 & $75,0 \%$ \\
\hline 2 & Tidak Merokok & 36 & $25,0 \%$ \\
\hline & Jumlah & 144 & 100 \\
\hline
\end{tabular}

proporsi $(61,1 \%)$ dan responden anak balita yang tidak menderita ISPA sebesar 56 proporsi $(38,9 \%)$. 
Berdasarkan Tabel 3 di atas dari 144 sampel di dapatkan distribusi frekuensi bahwa anak balita yang menderita ISPA sebanyak 108 proporsi $(75,0 \%)$ dan responden anak balita yang tidak menderita ISPA sebesar 36 proporsi $(25,0 \%)$

\section{Ventilasi Asap Dapur}

Tabel 4

Distribusi Frekuensi ISPA Pada Anak Balita Di Desa Sukapindah Wilayah Kerja UPTD Puskesmas Kedaton Peninjauan Raya Kabupaten OKU Tahun 2019

\begin{tabular}{llll} 
No & Ventilasi asap dapur & Frekuensi & \% \\
\hline 1 & Tidak mempunyai & 80 & $55,6 \%$ \\
\hline 2 & Mempunyai & 64 & $44,4 \%$ \\
\hline & Jumlah & 144 & 100
\end{tabular}

Berdasarkan Tabel 4 di atas dari 144 sampel di dapatkan distribusi frekuensi bahwa anak balita yang menderita ISPA sebanyak 80

\section{Kepadatan Hunian}

\section{Tabel 5}

Distribusi Frekuensi ISPA Pada Anak Balita Di Desa Sukapindah Wilayah Kerja UPTD Puskesmas Kedaton Peninjauan Raya Kabupaten OKU Tahun 2019

\begin{tabular}{llll} 
No & Kepadatan Hunian & Frekuensi & \% \\
\hline 1 & Padat & 80 & $55,6 \%$ \\
\hline 2 & Tidak Padat & 64 & $44,4 \%$ \\
\hline & Jumlah & 144 & 100 \\
\hline
\end{tabular}

Berdasarkan Tabel 5 di atas dari 144 sampel di dapatkan distribusi frekuensi bahwa anak balita yang menderita ISPA sebanyak 80 proporsi $(55,6 \%)$ dan responden anak proporsi $(55,6 \%)$ dan responden anak balita yang tidak menderita ISPA sebesar 64 proporsi $(44,4 \%)$.

Tabel 6

Hubungan Pemakaian Obat Nyamuk Bekar Dengan Kejadia ISPA Pada Balita

\begin{tabular}{|c|c|c|c|c|c|c|c|c|}
\hline \multirow[t]{3}{*}{ No } & \multirow{3}{*}{$\begin{array}{l}\text { Pemakaian obat } \\
\text { nyamuk bakar }\end{array}$} & \multicolumn{4}{|c|}{ ISPA pada balita } & \multirow{3}{*}{ Jumlah } & \multirow{3}{*}{$\%$} & \multirow{3}{*}{$P$ value } \\
\hline & & \multicolumn{2}{|c|}{$\mathrm{Ya}$} & \multicolumn{2}{|c|}{ Tidak } & & & \\
\hline & & $\mathrm{N}$ & $\%$ & $\mathrm{~N}$ & $\%$ & & & \\
\hline 1 & Pakai & 70 & $79,5 \%$ & 18 & $20,5 \%$ & 88 & $100 \%$ & \\
\hline \multirow[t]{2}{*}{2} & Tidak pakai & 20 & $35,7 \%$ & 36 & $64,3 \%$ & 56 & $100 \%$ & 0,000 \\
\hline & Total & 90 & $62,5 \%$ & 54 & $37,5 \%$ & 144 & $100 \%$ & \\
\hline
\end{tabular}


Dari Tabel 6 di atas penderita ISPA pada balita sebanyak 90 proporsi $(62,5 \%)$ responden dengan pemkaian obat nyamuk bakar yang balita menderita ISPA sebanyak 70 proporsi $(79,5 \%)$,lebih besar dari responden yang tidak memakai obat nyamuk bakar yang balita menderita ISPA sebanyak 20 proporsi $(35,7 \%)$.

Hasil uji chi-squere di peroleh $p$ value 0,000. Hal ini berarti ada hubungn yang bermakna antara pemakaian obat nyamuk bakar dengan kejadian ISPA pada balita.

Hubungan perilaku merokok dengan kejadian ISPA

Tabel 7

Hubungan perilaku merokok dalam rumah dengan kejadian ISPA pda balita

\begin{tabular}{|c|c|c|c|c|c|c|c|c|}
\hline \multirow[t]{3}{*}{ No } & \multirow[t]{3}{*}{ Perilaku merikok } & \multicolumn{4}{|c|}{ ISPA pada balita } & \multirow{3}{*}{ Jumlah } & \multirow{3}{*}{$\%$} & \multirow{3}{*}{$P$ value } \\
\hline & & \multicolumn{2}{|c|}{$\mathrm{Ya}$} & \multicolumn{2}{|c|}{ Tidak } & & & \\
\hline & & $\mathrm{N}$ & $\%$ & $\mathrm{~N}$ & $\%$ & & & \\
\hline 1 & Merokok & 85 & $78,7 \%$ & 23 & $21,3 \%$ & 108 & $100 \%$ & \\
\hline \multirow[t]{2}{*}{2} & Tidak merkok & 5 & $13,9 \%$ & 31 & $86,1 \%$ & 36 & $100 \%$ & 0,000 \\
\hline & & 90 & $62,5 \%$ & 54 & $37,5 \%$ & 144 & $100 \%$ & \\
\hline
\end{tabular}

Hasil uji chi-squere di peroleh $p$ value 0,000 . Hal ini berarti ada hubungn yang bermakna antara perilaku merokok dalam rumah dengan kejadian ISPA pada balita.

Hubungan ventilasi asap dapur dengan kejadian ISPA

Tabel 8

Hubungan ventilasi asap dapur dengan kejadia ISPA pda balita

\begin{tabular}{|c|c|c|c|c|c|c|c|c|}
\hline \multirow[t]{3}{*}{ No } & \multirow{3}{*}{$\begin{array}{l}\text { Ventilasi } \\
\text { dapur }\end{array}$} & \multicolumn{4}{|c|}{ ISPA pada balita } & \multirow{3}{*}{ Jumlah } & \multirow{3}{*}{$\%$} & \multirow{3}{*}{$P$ value } \\
\hline & & \multicolumn{2}{|c|}{$\mathrm{Ya}$} & \multicolumn{2}{|c|}{ Tidak } & & & \\
\hline & & $\mathrm{N}$ & $\%$ & $\mathrm{~N}$ & $\%$ & & & \\
\hline 1 & Tidak mempunyai & 60 & $75,0 \%$ & 20 & $25,0 \%$ & 80 & $100 \%$ & \\
\hline \multirow[t]{2}{*}{2} & Mempunyai & 30 & $46,9 \%$ & 34 & $36,1 \%$ & 64 & $100 \%$ & 0,001 \\
\hline & & 90 & $62,5 \%$ & 54 & $37,5 \%$ & 144 & $100 \%$ & \\
\hline
\end{tabular}

Dari Tabel 8 di atas penderita ISPA pada balita sebanyak 90 proporsi $(62,5 \%)$ responden yang tidak memepunyai ventilasi asap dapur yang balita menderita ISPA sebanyak 60 proporsi $(75,0 \%)$,lebih besar dari responden yang mempunyai ventilasi asap dapur yang balita menderita ISPA sebanyak 30 proporsi $(46,9 \%)$.

Hasil uji chi-squere di peroleh $p$ value 0,001. Hal ini berarti ada hubungn yang bermakna antara ventilasi asap dapur dengan kejadian ISPA pada balita. 
CENDEKIA MEDIKA

Volume 5 Nomor 1 ,

April 2020 p-ISSN: 2503-1392

e-ISSN: 2620-5424

Hubungan kepadatan hunian dengan kejadian ISPA

Tabel 9

Hubungan Kepadatan Hunian Dengan KejadiaN ISPA Pada Balita

\begin{tabular}{|c|c|c|c|c|c|c|c|c|}
\hline \multirow[t]{3}{*}{ No } & \multirow[t]{3}{*}{ Kepadatan hunian } & \multicolumn{4}{|c|}{ ISPA pada balita } & \multirow{3}{*}{ Jumlah } & \multirow{3}{*}{$\%$} & \multirow{3}{*}{$P$ value } \\
\hline & & \multicolumn{2}{|c|}{ Ya } & \multicolumn{2}{|c|}{ Tidak } & & & \\
\hline & & $\mathbf{N}$ & $\%$ & $\mathbf{N}$ & $\%$ & & & \\
\hline 1 & Padat & 65 & $81,2 \%$ & 15 & $18,8 \%$ & 80 & $100 \%$ & \\
\hline \multirow[t]{2}{*}{2} & Tidak padat & 25 & $39,1 \%$ & 39 & $60,9 \%$ & 64 & $100 \%$ & 0,000 \\
\hline & & 90 & $62,5 \%$ & 54 & $37,5 \%$ & 144 & $100 \%$ & \\
\hline
\end{tabular}

Dari Tabel 9 di atas penderita ISPA pada balita sebanyak 90 proporsi $(62,5 \%)$ responden dengan kepadatan hunian yang balita menderita ISPA sebanyak 65 proporsi $(81,2 \%)$,lebih besar dari responden yang huniannya tidak padat yang balita menderita ISPA sebanyak 25 proporsi $(39,1 \%)$. Hasil uji chi-square di peroleh $p$ value 0,000 . Hal ini berarti ada hubungan yang bermakna antara kepadatan hunian dengan kejadian ISPA pada balita. 


\section{PEMBAHASAN}

Hubungan pemakaian obat nyamuk bakar dengan kejadian ISPA pada balita. Dari hasil penelitian di atas penderita ISPA pada anak balita penderita ISPA pada balita sebanyak 90 proporsi $(62,5 \%)$ responden dengan pemakaian obat nyamuk bakar yang balita menderita ISPA sebanyak 70 proporsi $(79,5 \%)$,lebih besar dari responden yang tidak memakai obat nyamuk bakar yang balita menderita ISPA sebanyak 20 proporsi $(35,7 \%)$.

Hasil uji statistik Chi-Square peroleh $p$ value 0,000.Hal ini berarti ada hubungan yang bermakna antara pemakaian obat nyamuk bakar dengan kejadian ISPA pada balita.

Penelitian ini sesuai dengan penelitian yang di lakukan oleh soffia (2017) di aceh, menyebutkan ada hubungan bermakna antara pemakaian obat nyamuk bakar dengan kejadian ISPA dengan nilai $p$ value 0,003.Begitu pula dengan penelitian Saleh dkk (2017) tentang hubungan sumber polutan dalam rumah dengan kejadian ISPA pada balita di kecamatan Mariso kota Makassar pemakaian obat nyamuk bakar perlu di waspadai oleh penderita ISPA ${ }^{7,8}$.

Pemakaian obat nyamuk bakar ini perlu diwaspadai (confounding) apabila faktor lingkungan rumah yang lain tidak mendukung seperti luas ventilasi kurang. Untuk mengurangi penggunaan obat nyamuk bakar di dalam rumah, keluarga dapat menggunakan cara tradisional yaitu memasang kelambu pada tempat tidur, menjaga kebersihan rumah dan sekitarnya, memasang kasa nyamuk pada pintu dan jendela, menggunakan raket anti nyamuk. Menggunakan anti nyamuk hanya sesuai keperluan, untuk ruang tertutup sebaiknya menggunakan bentuk semprot(selama penyemprotan sebaiknya tidak ada orang lain di dalam ruangan, dan ruang baru dimasuki setelah 2-3 jam) untuk ruang ber-AC sebaiknya tidak menggunakan anti nyamuk apapun karena dapat membuat zat kimia terakumulasi, jika terpaksa menggunakan anti nyamuk bakar atau elektrikmaka ruangan ha-rus selalu terbuka sepanjang pemakaian, serta menghindarkan anak-anak (balita) dari kontak dengan anti nyamuk (lotion anti nyamuk baru boleh diberikan pada anak-anak yang berusia di atas 9 tahun dan dioleskan secukupnya saja.

Prinsipnya semua anti nyamuk memang mengandung zat kimia yang dapat menjadi racun, karena itu harus digunakan dalam jumlah yang seminimal mungkin (sesuai kebutuhan). Selain itu, penyuluhan tentang bahaya asap obat nyamuk bakar juga harus dilaksanakan oleh pihak pemerintah maupun pihak Puskesmas kepada masyarakatnya di desa Sukapindah kecamatan Kedaton Peninjauan Raya.

Hubungan keterpaparan asap rokok dengan kejadian ISPA pada anak balita . Dari hasil penelitian penderita ISPA pada balita sebanyak 90 proporsi $(62,5 \%)$ responden dengan perilaku merokok rumah yang balita menderita ISPA sebanyak 85 proporsi $(78,7 \%)$,lebih besar dari responden yang tidak merokok dalam 
rumah yang balita menderita ISPA sebanyak 5 proporsi $(13,8 \%)$.

Hasil uji statistik chi-square di peroleh $p$ value 0,000 hal ini berarti ada hubungan yang bermakna antara perilaku merokok dengan kejadian ISPA pada balita.

Penelitian ini sesuai dengan penelitian soffia (2017) dari hasil uji satatistik di peroleh nilai $\mathrm{p}$ value 0,000 dengan $\mathrm{OR}=37,71$ menunjukkan bahwa balita yang tinggal di rumah dengan adanya perokok dalam rumah lebih rentan terserang penyakit ISPA ${ }^{7}$.

Kejadian ISPA pada balita akiba faktor lingkungan fisik bisa diperparah dengan perilaku orang tua di rumah yang tidak menerapkan aspek-aspek PHBS, salah satunya yang diteliti dalam penelitian ini adalah perilaku merokok. Dalam hal ini, perilaku merokok orang tua atau anggota keluarga tersebut yang dilakukan di dalam rumah atau di dalam ruangan tempat tinggal, terutama rumah yang terdapat balita. Padahal satu batang rokok yang dibakar akan mengeluarkan sekitar 4.000 bahan kimia seperti nikotin, karbon monoksida, nitrogen oksida, hidrogen sianida, amoniak, acrolein, artcresor, peryline dan lain-lain yang sangat berbahaya bagi tubuh manusia.Pangkal masalah dari rokok adalah munculnya pecandu. Zat kimia utama yang menyebabkan seseorang kecanduan rokok adalah nikotin. Ketika rokok dihisap,nikotin yang terkandung di dalamnya akan masuk ke saluran pernafasan dan lalu masuk ke dalam darah. Hanya diperlukan 8-10 detik bagi nikotin untuk sampai ke bagian otak. Saat nikotin sampai ke otak, akan muncul reseptor yang menangkap nikotin itu dan melepaskan dopamin, yaitu neurotransmitter yang membantu mengontrol pusat kepuasan dan kesenangan di otak. Karena itu, efek yang muncul pada saat merokok adalah rasa nyaman dan tenang. Itulah sebabnya mengapa perokok, terutama mereka yang mengalami depresi,akan merasa nyaman. Namun, dalam 10-15 menit, kadar dopamin akan turun kembali dan rasa nyaman pun hilang.

Merokok yang berulang-ulang selanjutnya akan menyebabkan reseptor nikotin di dalam otak kian banyak. Tubuh juga akan makin nyaman karena dopamin yang dikeluarkan juga bertambah banyak. Pada kondisi itu, tubuh biasanya akan terus menagih nikotin. Ketika seorang perokok tidak merokok, akan terasa ada yang kurang, dan apabila seorang perokok tiba-tiba berhenti merokok,maka ia akan mengalami gejala "sakau". Gelisah, sakit kepala, mudah marah,emosional, bahkan depresi adalah gejala umum yang muncul pada orang yang berhenti merokok. Tubuh yang sudah merasa nyaman ketika mendapat asupan nikotin, akan menagih nikotin lagi ${ }^{9}$.

Berdasarkan pengamatan dari peneliti bahwa keberadaan perokok dalam rumah yang memiliki balita mempengaruhi kesehatan anak balita tersebut.Peneliti menemukan bahwa kepala keluarga di desa Sukapindah masih banyak yang merokok dalam rumah walaupun ada anak balita di dalam rumah.Kebiasan merokok ini di karnakan kurangnya pengetahuan masyarakat tehadap bahaya asap 
rokok yang di tibulkan terhadap anak balita dan juga salah satu faktor adalah kebiasaan.Anaka balita yang terpapar asap rokok kemungkinan besar menderita gangguan saluran pernafasan seperti flu,pneumonia dan saluran nafas lainya.Karna asap rokok merangsang pembentukan lendir dalam paru-paru yang menyebabkan terjadinya ISPA pada anak balita sebaiknya orang tua balita yang merokok di lakuakn di luar rumah dan menjauh dari anggota keluarga yang lainnya saat merokok.

Hubungan ventilasi asap dapur dengan kejadian ISPA pada balita. Dari hasil penelitian ISPA pada balita yang menderita ISPA sebanyak 90 proporsi $(62,5 \%)$ responden yang tidak memepunyai vemtilasi asap dapur yang balita menderita ISPA sebanyak 60 proporsi $(75,0 \%)$, lebih besar dari responden yang mempunyai ventilasi asap dapur yang balita menderita ISPA sebanyak 30 proporsi $(46,9 \%)$.

Hasil uji statistik chi-square di peroleh $p$ value 0,001 . Hal ini berarti ada hubungan yang bermakna antara ventilasi asap dapur dengan kejadian ISPA pada balita.

Penelitian ini sesuai dengan penelitian yang di lakukan oleh wahyuningsih dkk (2017) melalui situs online,menyebutkan bahwa ada hubungan antara luas ventilasi dengan ISPA pada balita di wilayah pesisir desa kore kecamatan sanggar kabupaten bima, dengan nilai $\mathrm{p}$ value 0,000. Begitu pula dengan hsil penelitian yang di lakukan oleh ramadhaniyati dkk (2015) melalui situs online,diperoleh hasil uji statistik nilai $\mathrm{p}=0,041 \quad(\mathrm{p}<0,05)$ menunjukan bahwa ada hubungan antara luas ventilasi rumah dengan kejadian ISPA pada balita. Nilai RP= 2,446 dengan rentang $\mathrm{CI}=0,990$ 6,039 maka luas ventilasi rumah bukan faktor risiko dari kejadian ISPA pada balita ${ }^{10}$.

Ventilasi penting untuk menjamin ketersediaan dan mengalirkan udara dalam ruangan. Dengan adanya pergerakan udara oleh ventilasi diharapkan mikroorganisme penyebab ISPA dapat dibuang dan terbawa aliran udara keluar sehingga dalam ruang bersih dari penyebab ISPA. Namun apabila ventilasi rumah tidak memenuhi syarat kesehatan dapat membahayakan saluran pernafasan dikarenakan kelembaban dalam rumah menjadi tinggi akibat proses penguapan cairan dari kulit sehingga dapat menjadi tempat pertumbuhandan perkembangbiakan kuman patogen yang dapat mengakibatkan peningkatan risiko

Ventilasi berfungsi untuk menjaga sirkulasi udara dari dalam keluar dan dari luar kedalam rumah tetap terjaga sehingga keseimbangan oksigen $(\mathrm{O} 2)$ yang diperlukan penghuninya dapat terpenuhi dengan baik. Ventilasi dikategorikan baik apabila memenuhi syarat yaitu luas ventilasi $\geq 10 \%$ dari luas lantai dan terbuka dan dikategorikan tidak memenuhi syarat apabila $<10 \%$ dari luas lantai tetapi kondisi ini dapat diatasi dengan memasang kipas angin baik pada dinding ataupun plafon rumah agar sirkulasi udara dapat berjalan baik dan juga sering-sering membuka pintu pada saat pagi hari serta hindari penggunaan bahan-bahan furniture 
yang cepat menyerap kelembaban seperti kayu dan kulit ${ }^{12}$.

$\begin{array}{ccr}\text { Peraturan } & \text { Menteri } & \text { Kesehatan } \\ \text { Republik } & \text { Indonesia } & \text { No. }\end{array}$
077/MENKES/PER/V/2011 tentang Pedoman Penyehatan Udara Dalam Ruang Rumah yang menyatakan bahwa harus adanya ventilasi asap dapur disetiap rumah karena saat memasak akan terjadi proses pembakaran. Saat kayu dibakar, zat arang yang terkandung dalam kayu bereaksi pada oksigen dan berubah menjadi karbondioksida apabila terjadi pembakaran sempurna tetapi pada umumnya pembakaran yang tidak sempurna menghasilkan asap. Bahan bakar minyak tanah dan kayu bakar setelah mengalami pembakaran akan menghasilkan $\mathrm{CO}$ dan $\mathrm{CO} 2$, kedua macam polutan ini sangat berbahaya bagi kesehatan manusia dan dapat mengakibatkan keracunan apabila dihirup dalam jumlah yang banyak karena mengganggu fungsi kerja jantung dan paru-paru. Keadaan ini dapat dimodifikasi dengan memasang exhaustfan pada dinding dapur dan memasak ditempat yang jauh dari kamar tidur atau ditempat yang sirkulasi udaranya baiksehingga gas buang hasil proses memasak dapat dialirkan keluar ruangan ${ }^{12}$.

Berdasarkan penelitian yang dilakukan di desa Sukapindah bahwa ventilasi yang tidak memenuhi syarat mempengaruhi kemungkinan terjadinya ISPA pada balita.di desa sukapindah sendiri masih banyak rumah masyarakat yang tidak memiliki ventilasi asap dapur melainkan jendela,dan jendela itu sendiri jarang di buka ketika memasak.rumah dengan ventilasi asap dapur tidak memenuhi syarat dapat mempengaruhi kelembaban dalam ruangan,kelembaban ini merupakan salah satu media yang baik untuk pertumbuhan bakteri.sebaiknya masyarakat desa yang tidak memiliki ventilasi asap dapur untuk membuka jendela di dapur agar ada pertukaran udara ruangan.

Hubungan kepadatan hunian dengan kejadian ISPA pada balita. Dari hasil penelitian balita yang menderita ISPA sebanyak 90 proporsi $(62,5 \%)$ responden dengan proporsi hunian yang padat dan menderita ISPA pada balita sebanyak 65 proporsi $(61,5 \%)$ lebih besar dari hunian yang tidak padat yang menderita ISPA pada balita sebanyak 25 proporsi $(39,1 \%)$.

Hasil uji statistikchi-square di peroleh $p$ value 0,000 . Hal ini berarti ada hubungan yang bermakna antara kepadatan hunian dengan kejadian ISPA pada balita.

Penelitian ini sesuai dengan penelitian yang di lakukan oleh Wahyuningsih dkk (2017) dengan penelitian yang di lakukan oleh wahyuningsih dkk (2017). Hasil uji statistik dengan menggunakan uji chi square diperoleh nilai $p=0,000$, yang menunjukkan adanya hubungan antara kepadatan hunian dengan kejadi-an ISPA pada balita di Wilayah pesisir Desa Kore Kecamatan Sanggar kabupaten Bima tahun $2014{ }^{10}$. Hal ini sejalan dengan penelitian yang di lakukan oleh Pramudiyani dan Prameswari (2011) yang menyimpulkan ada hubungan antara kepadatan hunian dengan kejadian ISPA pada balita dengan nilaip value $0,001^{12}$. 
CENDEKIA MEDIKA

April 2020 p-ISSN: 2503-1392

e-ISSN: 2620-5424
Volume 5 Nomor 1,
Berdasarkan Permenkes, 829/ MENKES/ SK/ VII/ 1999, Kepadatan hunian dikatakan memenuhi syarat apabila luas ruangan tidur $8 \mathrm{~m} 2$ untuk dua orang. Bangunan yang sempit dan tidak sesuai dengan jumlah penghuninya akan mempunyai dampak kurangnya oksigen dalam ruangan sehingga daya tahan tubuh penghuninya menurun. Berdasarkan hasil Penelitian di lapangan, kepadatan hunian yang memenuhi syarat lebih dominan dibandingkan yang tidak memenuhi syarat, hal ini dikarenakan karakteristik dari rumah penduduk yang cukup luas.

Kepadatan hunian rumah akan meningkatkan suhu ruangan yang di sebabkan oleh penge-luaran panas badan yang akan meningkatkan kelembaban akibat uap air dari pernafasan tersebut. Dengan demikian semakin banyak penghuni rumah dan maka semakin cepat udara ruangan mengalami pencemaran gas atau bakteri. Dengan banyaknya penghuni, maka kadar oksigen dalam ruangan akan menurun di ikuti oleh peningkatan C2 ruangan dan dampak dari peningkatan $\mathrm{CO} 2$ ruangan adalah penurunan kualitas udara dalam rumah. Jumlah orang yang tinggal dalam satu rumah dapat mempengaruhi penyebaran Penyakit menular dalam kecepatan transmisi mikroorganisme. Kepadatan penghuni rumah yang terlalu tinggi dan kurangnya ventilasi menyebabkan kelembaban dalam rumah juga meningkat,dan dapat meningkatkan faktor polusi dalam rumah yang telah ada. Berdasarkan penelitian yang di lakukan di desa
Sukapindah ada hubungan yang bermakna antara kejadian ISPA pada balita dengan kepadatan hunian ini menandakan bahwa masih banyak rumah masyarakat desa sukapindah yang penghuninya melebihi kapasitas dari rumah itu sendiri sehingga menyebabkan udara yang pengap di dalam ruangan,adapun di desa sukaindah sendiri kepadatan hunian lebih dominan yang belum memenuhi syarat. 


\section{KESIMPULAN DAN SARAN}

Dari hasil wawancara dengan 144 responden sebagai sampel tentang kejadian ISPA pada balita di desa sukapindah wilayah kerja UPTD puskesmas Kedaton Peninjauan Raya kabupaten OKU seperti yang di uraikan pada $\mathrm{BAB}$ sebelumnya maka penulis dapat mengambil kesimpulan sebagai berikut.

Ada hubungan bermakna antara pemakaian obat nyamuk bakar dengan kejadian ISPA pada balita di desa sikapindah wilayah kerja UPTD puskesmas kedaton peninjauan raya kabupaten OKU tahun 2019 degan $p$ value 0,000.

Ada hubungan yang bermakna antara perilaku merokok dalam rumah dengan kejadian ISPA pada balita di desa sukapindah wilayah kerja UPTD puskesmas kedaton peninjauan raya kabupaten $\mathrm{OKU}$ tahun 2019 dengan p value 0,000.

Ada hubungan bermakna natara ventilasi asap dapur dengan kejadian ISPA pada balita di desa sukapindah wilayah kerja UPTD puskesmas kedaton peninjauan raya kabupaten OKU tahun 2019 dengan $p$ value 0,001 .

Ada hubungan bermakna antara kepadatan hunian dengan kejadian ISPA pada balita di daesa sukapindah wilayah kerja UPTD puskesmas kedaton peninjauan raya kabupaten OKU tahun 2019 dengan $p$ value 0,000 .

Sesuai dengan hasil penelitian yang penulis lakukan maka penulis memberikan beberapa masukan untuk membantu dan meningkatkan pelaksanaan penurunan kejadian ISPA pada anak balita sebagai berikut.

Hendaknya masyarakat desa tidak memakai obat nyamuk bakar dan gunakan kelambu atau lotion anti nyamuk utuk mencegah gigitan nyamuk,agar dapat mencegah kemungkinan terjadinya ISPA pada balita.

Merokok dalam rumah sendiri sebenarnya tidak di salahkan tapi alangkan baiknya prilaku merokok di lakukan ketika berada di luar rumah,agar tidak mencemari udara di dalam rumah.

Untuk mendapatkan cahaya matahari yang cukup di dalam rumah,di perlukan luas ventilasi dan jendela yang memenuhi syarat kesehatan. Kaluapun tidak memiliki ventilasi haruslah jendela di rumah sering di buka agar ruamh mendapatkan pencahayaan yang cukup untuk membunuh bakteri yang ada di dalam rumah.

Luas bangunan rumah seharusnya cukup untuk penghuni di dalamnya,jadi hendaknya bangunan rumah tersebut di sesuaikan dengan jumlah penghuninya agar tidak mempermudah pertukaran udara dalam rumah. 


\section{DAFTAR PUSTAKA}

1. Adesanya, O. A., \& Chiao, C. (2017). Environmental risks associated with symptoms of acute respira.(UPTD PKM Kedaton, 2019).tory infection among preschool children in North-Western and SouthSouthern Nigeria Communities. International Journal of Environment Research and Public Health, 14(11), 1-10. https://doi.org/10.3390/ijerph141 $\underline{11396}$

2. Mahendrayasa, dkk, 2018.Hubungan Antara Kondisi Fisik Rumah Dengan Kejadian Infeksi Saluran Pernafasan Atas Pada Balita Di Surabaya.

3. WHO. (2017). Pneumonia. Geneva: World Health Organization. Retrieved September 22, 2018, from http://www.who.int

4. Saleh, dkk, 2017. Hubungan Sumber Polutan dalam Rumah Dengan Kejadian Infeksi Saluran Pernafasan Akut pada Balita di Kecamatan Mariso Kota Makassar.

5. Dinas Kesehatan Baturaja Kabupaten Ogan Komering Ulu. 2019. Profil Dinas Kesehatan Baturaja Kabupaten Ogan Komering Ulu. Dinas Kesehatan Baturaja Kabupaten Ogan Komering Ulu.

6. Profil UPTD PKM Kedaton, 20192.
7. Soffia, 2017. Faktor Risiko Lingkungan Dengan Kejadian Ispa Pada Balita Di Wilayah Kerja Puskesmas Ingin Jaya Kabupaten Aceh Besar.

8. Saleh, dkk, 2017. Hubungan Sumber Polutan dalam Rumah Dengan Kejadian Infeksi Saluran Pernafasan Akut pada Balita di Kecamatan Mariso Kota Makassar.

9. Pangestika, dkk, 2015. Hubungan Perilaku Merokok Di Dalam Rumah Dan Penggunaan Obat Nyamuk Bakar Dengan Kejadian Ispa Pada Balita Di Kelurahan Semarang, Kecamatan Banjarnegara, Kabupaten Banjarnegara. Poltekes Kemenkes yogyakarta :MEI 2015

10. Wahyuningsih, dkk, 2017. Infeksi Saluran Pernafasan Akut (ISPA) pada Balita di Wilayah Pesisir Desa Kore Kecamatan Sanggar Kabupaten.

11. Kementrian Kesehatan. 2018. Profil Kesehatan Republik Indonesia. Jakarta, Kementrian Kesehatan RI.

12. Pramudiyani dan Prameswari, 2011. Hubungan Antara Sanitasi Rumah Dan Perilaku Dengan Kejadian Pneumonia Balita. 